\title{
On the Identity of Shahrālānyōzān in the Greek and Middle Persian Papyri from Egypt
}

\author{
Jairus Banaji
}

'Shahrālānyōzān' appears in several Greek and Middle Persian papyri from Egypt, as well as a couple of ostraca in Greek and at least one parchment in Middle Persian. ${ }^{1}$ John Rea has published two of the Greek papyri as P.Oxy.3637 and 3797 , and noted that P.Oxy. 1843 (from vol. xvi), which does not mention Shahralanyozan by name, is in the same hand and deals with the same transaction as P.Oxy. $3637 .^{2}$ During the publication of this new material, Poethke confirmed that Shahralanyozan also appears in $B G U$ II 377, and Worp suggested that he could also be found in SPP X 251 (in the Louvre), a suggestion confirmed by Gascou. ${ }^{3}$ The Oxyrhynchite material contains more or less precise dates and from this it is clear that this official, whoever he was, was active in Egypt in the 620s, a period when the country was under Persian occupation. The Greek material is also better preserved and more substantial in content than any of the published Persian papyri or parchments. Three of the Greek papyri are about the payment of large sums of gold, due for shipment out of Egypt, in a twelfth indiction which is dated 623/4. A fourth one, and possibly a fifth one as well, is part of the internal administration of a large Fayyumic estate that had passed into Shahralanyozan's control. One of the Fayyūm documents, an account involving disbursements of cash, refers to the oikos of Shahralanyozan

$1 \quad$ P.Oxy. LI 3637 (19(?).x.623); LV 3797 (26.iv-25.v.624); SPP X 251 (626/7; 7c. in $B L$ 9.343), and $B G U$ II 377 (7th century) contain references to someone called $\Sigma \alpha \rho \alpha \lambda \alpha \nu \varepsilon \circ \zeta \alpha \nu$, transliterated 'Saralaneozan' in P.Oxy., while the presence of the same individual is implied in P.Oxy. XVI 1843 (6.xi.623, BL 8.250). The most interesting published Middle Persian documents that mention Shahrālānyōzān are CII Nos. 5, 58, and 81 in Weber, Ostraca 118, 161, and 185 respectively), P. 136 and P. 172 in Weber, Berliner Papyri, and the leather parchment Wien P.Pehl. 373a (Weber, Eine spätsassanidische $185 \mathrm{ff}$.).

2 Rea, P.Oxy. 3637.14n (LI, p. 103f.), with Gershevitch's suggestion that 'Shahrālānyōzān' should be seen as a title with the (tentative) meaning 'most powerful of commanders.' Here Gershevitch derives -yozan from Av. aojah-, 'power,' e.g. Kellens and Pirart, Les textes 2:198, which I find an odd interpretation in view of his commentary on Yasht 10, 36, see Gershevitch, The Avestan hymn 187. Contrast my explanation below.

3 Ibid., and 3797.9n (LV, p. 78).

(C) JAIRUS BANAJI, 2015 | DOI:10.1163/9789004284340_004

This is an open access chapter distributed under the terms of the prevailing CC-BY-NC License at the time of publication. 
and refers to the estate as an ousía. ${ }^{4}$ It also mentions someone who appears to be his wife or one of his wives, calling her endoxotate kyría. ${ }^{5}$ She was based in Alexandria. In contrast to all of this, the Middle Persian documents, which are also from the Fayyūm, are simply scraps of papyrus or parchment and do not directly concern the affairs of Shahralanyozan. ${ }^{6}$ The picture would probably have been different, perhaps even radically different, if the very substantial collection of Middle Persian papyri acquired by the Nationalbibliothek in Vienna in the late nineteenth century had not disappeared, almost in its entirety, following its loan to Berlin in the 1930s. ${ }^{7}$

To sum up, the Greek material falls into two groups: Oxyrhynchite documents, almost certainly from the former Apion estate, ${ }^{8}$ involving substantial payments of gold, upwards of 150 lbs from just two districts, and the two Fayyūm papyri which are less overtly public in tone. Now the most striking feature of the Greek papyri and the two ostraca from Hermonthis is that Shahralanyozan is described as paneuphèmos in almost all of them. I believe this is a fairly strong clue that papyrologists have failed to pick up on. Absolutely no one but the most powerful and wealthy section of the Byzantine aristocracy described themselves in this way. ${ }^{9}$ In other words, if we approach the issue of the identity of this mysterious individual in a purely abstract, logical way, to begin with, he would have had to have been a high-ranking Sasanian official with sufficient stature to justify the extraordinary step of deploying the one epithet that distinguished the élite sections of the Byzantine aristocracy. This restricts the choice to a handful of the highest ranking officials in charge of the Sasanian occupation of the eastern provinces. ${ }^{10}$ Of course, one can always assume that not all

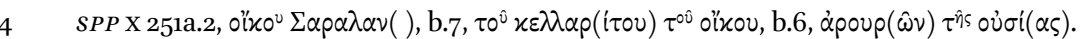

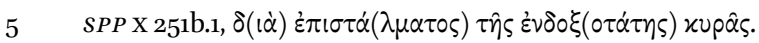

6 Wien P.Pehl. 373a (Weber, Eine spätsassanidische 185 ff.) mentions the "seal of Šahrālānyōzān" in l. 10 (gilēnag pad muhr i Šahr-Ālānyōzān āwištt).

7 See Weber, Pahlavi Papyri 27-28.

8 I cannot prove this, but the consolidation of the Oxyrhynchite and the Cynopolite for tax purposes otherwise occurs only in Apion documents.

E.g. Flavius Strategius son of Flavius Apion I, his son Flavius Apion II, and Flavius Athanasius from the sixth century; Flavius Strategius (the Fayyūm Strategius), Flavius Apion III in the seventh, including some lesser known aristocrats such as Leon in P.Laur. III 110 (615); an epithet typical of patricii.

10 On the military side, the chief rival to Shahrvaraz appears to have been the Sasanian commander called Kardarigas by Theophanes, Chronicle, 421 etc. AM 6097. Although titles like this came to be used as personal names, there is no indication in the sources of who this person was. On the name, cf. Theophylact Simocatta, History, 32. 1.9.6), "This [the Kardarigan] is a Parthian title; the Persians like to be called by their titles, as if they consider it 
of these officials are known to us, and so it is always possible that 'Shahralanyozan' conceals a powerful figure of Khusrō II's administration who has simply escaped the attention of the sources. This is possible but unlikely. What I would like to do in this paper is suggest grounds for identifying Shahralanyozan with Shahrvaraz, the powerful general who led Khusrō's invasion of Mesopotamia in $608 / 9$ (probably earlier as well), of Syria in 610, and, most notoriously, of Palestine in $613 .{ }^{11}$ His actual name was Farrukhān, but as Movses Dasxurants'i tells us, Khusrō "called him various fancy names, now Razmiozan and now Šahrvaraz, on account of his advances, attacks and victories won by Persian cunning." ${ }^{12}$ Shahrvaraz does not appear to have been from the more traditional layers of the Sasanian aristocracy and, as much later events demonstrated, was in fact hated by them. ${ }^{13}$ From the Syriac sources we can tell, first, that Shahrvaraz supported Khusrō in the conflict with Bahram Chobin late in 590 and much of

unworthy to bear their birth-names," drawing on the History of John of Epiphania, who was acquainted with members of the Sasanian ruling elite, as he tells us, see Olajos, Les sources esp. $14 \mathrm{ff}$. on John's access to Persian sources and his visit to the country.

The assault on Mesopotamia was protracted and Shahrvaraz may not have been involved throughout: Khuzistan Chronicle 19; Nöldeke, Die von Guidi 16-17; Chronicle of AD 1234 (henceforth 'Dionysius' = Dionysius of Tel-Mahré) 14, in Palmer, The seventh century 122; Sebeos, The Armenian history 110 f. (63); Syria: Chronicle composed AD 640, AG 921, in Palmer The seventh century 17, "On 7 August of the same year [610] Shahrvarāz crossed to Zenobia and took it," our one precise date; Jerusalem: Sebeos, The Armenian history 115f. (p. 69), precise details with the number of killed put at 17,000 (57,000 in later Armenian sources, a misreading of Sebeos' figure; 90,00o in Michael the Syrian and Bar Hebraeus).

12 Movses Dasxurants'i, The history 77, based on a high-quality seventh-century source that terminates its own narrative in the early 680s, cf. Howard-Johnston, Armenian historians, esp. $5^{2}$ ff. (Note Greenwood's statement that the History of the Albanians has been wrongly attributed to Dasxurants'i, Greenwood, Armenian neighbours 339, n. 14.) Farrukhān, Khuzistan chronicle, 25; Nöldeke, Die von Guidi 31; al-Tabarī (d. 310/923), Ta’rīkh al-rusulwa-l-mulūk 1:1062, فرّرَّان, so too Ibn al-Athīr (d. 630/1233), al-Kāmil fì al ta'rīkh 1:475; Xoream etc. in the Armenian sources, cf. Hübschmann, Armenische grammatik 42, no. 78 . Cf. note 40 below. Pourshariati's suggestion that Shahrvarāz turns up on one of Gyselen's seals from the Saeedi collection as Pirag ¿ ¿ šahrwarāz (described as 'spāhbed of the Southern Quarter' and a 'grandee', wuzurg, hailing from the Mihrān family), Pourshariati, Recently discovered seals 175 , with Gyselen, The four generals $40-41$, seal $2 \mathrm{~d} / 2$, is an improbable one on several counts. (1) There is never any indication in the sources that S. was from the Mihrān clan, which is odd if he had been and the fact was well-known. (2) Gyselen is strongly inclined (on internal grounds) to date the spähbed seals that have the expression hujadag-Khusrō to the reign of Khusrō I, see Gyselen, Sasanian seals $49 \mathrm{ff}$., Gyselen, Primary sources 18o ff., supported by Cereti, On the Pahlavi cursive esp. 184, n. 24. (3) Al-Mas'ū ūi describes S. as spāhbed of the West. 
$591,{ }^{14}$ and second, that at the time of Maurice's assassination in 602, Shahrvaraz/Farrukhān was already an experienced general. ${ }^{15}$

The main arguments for identifying him with Shahralanyozan are: (1) the mainly Syriac (Syrian Jacobite) tradition that attributes the conquest of Alexandria in 619 to Shahrvaraz; ${ }^{16}$ (2) Sebeos' crucial testimony that it was Shahrvaraz who controlled Alexandria in 629 when Heraclius opened negotiations with him for the treaty that was eventually concluded at Arabissus in July of that year; ${ }^{17}$ (3) the curious if not striking coincidence in the morphology of the names Shahralanyozan and Razmyozan, the latter being Shahrvaraz's most common appellation in the Armenian sources (which generally refer to him as Xoream, i.e., Farrukhān);18 (4) a tradition preserved in al-Ṭabarī which asso-

14 'Dionysius' 8, in Palmer, The seventh century 117, "When he [Bahram] heard of Chosroēs' return, he made ready to do battle with him. When Chosroēs reached Persian territory, the general Rōmēzān joined him, adding his 10,00o Persians to the army of the Romans, and became his ally." Khusrō succeeded Hormazd shortly after 27 June 591 and was restored to the throne in autumn of that year, cf. Tyler-Smith, Calendars and coronations.

15 'Dionysius' 14, in Palmer, The seventh century 121, "... Rōmēzān, a powerful, dedicated man with considerable experience in combat ..."

16 'Dionysius' 24, in Palmer, The seventh century 128. "Shahrvarāz invaded Egypt and, with much bloodshed, subjected it with Alexandria to the Persians" (Michael the Syrian, Chronique de Michel 2:401; Bar Hebraeus, The chronography 1:87).

17 Sebeos, The Armenian history 129 (p. 88), "Then Khoream was easily persuaded, and he abandoned Alexandria." Stephanos Asoghig may have read this in Sebeos, if not, he provides interesting corroboration, cf. Histoire 148-149: "Héraclius écrivit au général perse Khor'em qui était alors du côté d'Alexandrie pour l'inviter à venir le trouver ..."

18 I shall suggest an interpretation of $-y(a)$ ozan later (see below). For the name, cf. Dele-

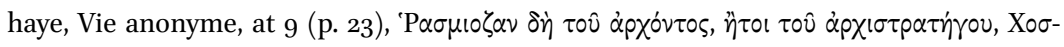
póou $x \tau \lambda$., (Cf. Leontius of Neapolis, Vie de Syméon le fou et vie de Jean de Chypre, 325), Lappa-Zizicas, Un épitomé inédit at 9 (p. 276) (both based on the lost 'Life' of John by John Moschus and Sophronius, so our two earliest references), Theophanes, (Chronicle 421), 'Rousmiazan'; Sebeos, The Armenian history 110 (p. 62), "Khoream called Ěrazman" 115 (p. 68), "their general, called Razmiozan, that is, Khoream" (p. 69) "Khoream, that is Ěrazmiozan" etc., Dasxurants'i, History (n. 12 above), Thomas Artsruni, History 155-156, "Ṙazmayuzan also called Khoream," and "Khoream Razmayuzan," Stephanon Asoghig, Histoire 146, "le général Khor'em surnommé Razman;" Strategius [Georgian text], Prise de Jérusalem, ix.2 (p. 16), "Rasmiozdan,' xxiv. 3; 6 (p. 54), "Rasmiozan;” Garitte, Expugnationes Hierosolymae 191, رسميسة (rsmysa); 'Dionysius' 8, in Palmer, The seventh century 117, "the general Rōmēzān," 14 (p. 122), "Chosroēs exclaimed, "Then your name is not Rōmēzān but Shahrvarāz, the Wild Boar!'”, Mich. Syr., Chronique de Michel (n. 16), 2, 377, "Romîzan," Bar Hebraeus, The chronography 1, 87, "Rûmîzân, the captain of the host, who was nicknamed 'shahrbarAz';” al-Ṭabarī, Ta’rīkh 1:1002, l. 3, رُميوزان. 
ciates the family of Shahrvaraz with Darband (on the Caspian coast) coupled with the fact that Darband stood at the heart of a defensive system designed to consolidate Sasanian control of the Caucasian region (k'usti kapkoh) against the incursions of the Alans and other tribal groups. There is some reason to believe that šahr i $\bar{A} l \bar{a} n$ referred to much of the territory to the north and west of Darband, at least until the Khazars became a major force in the eastern Caucasus..$^{19}$ Finally, there is the extraordinary report which we owe entirely to Nikephoros, patriarch of Constantinople, that at least one daughter and one son of Shahrvaraz became Christians (with the names Nike and Niketas). Indeed, the understanding between Heraclius and Shahrvaraz included the betrothal of Shahrvaraz's daughter Nike to Heraclius' son Theodosius. ${ }^{20}$ This remarkable integration into the Greek-speaking Christian circles of the Byzantine aristocracy accords well with the impression conveyed by $S P P \times 251$ of a Sasanian official ('Saralaneozan') settling down to the ways of life of a local aristocrat, with an oikos, a substantial estate, in the Fayyūm and, who knows, many other districts.

To rehearse some of these arguments as briefly as I can, the Syriac tradition that it was Shahrvaraz who led the invasion of Egypt is prima facie contradicted by a second, divergent source tradition that attributes the conquest of Egypt to the Sasanian commander Shahin. This tradition is found in Nikephoros and al-Ṭabarī and in a passing reference in al-Dīnawarī. ${ }^{21}$ For the conquest and evacuation of Alexandria we have precise dates in a Mesopotamian chronicle composed c. 640 (known, misleadingly, as the 'Liber calipharum'). ${ }^{22}$ This gives us June 619 as the date of the capture of Alexandria. The later, ninth-century Syriac chronicle of Dionysius of Tel Mahré dated Shahrvaraz's invasion of Egypt to $617 / 8 .^{23}$ There is no conflict here if we assume that operations began in 618

19 Both Syriac and Arabic sources suggest that the Khazars were on the scene by the later sixth century (e.g. al-Ya'qūbī [d. after 292/905], Ta'rīkh 1:188, l. 2), but if so, it is hard to disentangle them from their Turkish overlords, the Western or Kök Türks.

20 Nikephoros, Short history, at 17 (p. 65): "Now Herakleios conferred the dignity of patrician upon Niketas, son of Sarbaros, and gave the latter's daughter Nike in marriage to his own son Theodosios, born of Martina;" cf. Mango, Deux études sur Byzance $105 \mathrm{ff}$.

21 Nikephoros, Short History 6 (p. 45), calling him "Saïtos"; al-Dīnawarī (d. 281-289/894-901), al-Akhbār al-țiwāl 112, ll. 14-15, al-Ṭabarī, Ta’rīkh 1:1002, l. 9 ff., followed by Ibn al-Athīr, alKāmil 1:475 (where al-Ṭabarīs ريوزان has become بوران!); in an earlier passage al-Dīnawarī, $A k h b \bar{a} r 110$ f., l. $19 \mathrm{ff}$. ascribes the capture of Alexandria and the search for the Cross (!) to a second commander (neither Shahīn nor Shahriyar = Shahrvarāz) whose name is clearly corrupt, cf. بوبوذذ القائدُ الاخر بوذ in the Cairo ed. of al-Dīnawarī).

22 Chronicle composed AD 640, AG 930, in Palmer, The seventh century 17-18.

23 'Dionysius,' 24, in Palmer, The seventh century 128. 
and culminated in the capture of Alexandria in the middle of 619, following what appears to have been a prolonged siege. In 617 Shahrvaraz was in Pisidia. ${ }^{24}$ Sebeos tells us that Shahin joined him there, and it is just possible that the invasion of Egypt started as a joint operation in the next campaigning season, which would explain why we have two traditions. In any case, if we do have to choose, the Syriac tradition is more credible. The passage in al-Tabari is a highly compressed summary of events ranging from 610 to 626 , and it is garbled..$^{25} \mathrm{It}$ posits three Sasanian commanders, but two of them were the same individual. Shahrvaraz appears first as "Rumiyūzān," i.e., Razmyozan (Khusrō "sent him to Syria which he then subdued and penetrated as far as Palestine"), and then as "Farruhān," i.e., Farrukhān, "with the rank of Shahrvaraz" ("He led an expedition to attack Constantinople, until he halted on the bank of the strait just near the city ..."). ${ }^{26}$ al-Tabari or the source he used had lost all narrative sense of these events, but he/his source was correct in describing Shahīn as pādgōsbān of the West and dating the start of the invasion to Khusrō's 28 th year. ${ }^{27}$ Finally, at least one strand of the Arabic historical tradition also attributed the siege or capture of Alexandria to Shahrvaraz, namely, the one found in al-Tha'ālibī and Abū 'Alī Miskawayh. ${ }^{28}$ This was clearly a different source to that used by al-Ṭabarī.

In short, if Shahrvaraz led the invasion of Egypt in 618/9 and was still in control of the country in 629 when, according to Sebeos, he "abandoned Alexandria," ${ }^{29}$ he was clearly the highest-ranking Sasanian in charge of Egypt in the 620s, and probably used Egypt as his major base of operations throughout these years. In 622 or 623 the Sasanians launched a naval offensive to seize Rhodes and other Byzantine possessions in the Mediterranean. ${ }^{30}$ The Syriac sources

\footnotetext{
24 Sebeos, The Armenian history 113 (p. 66), with Howard-Johnston's notes in pt. 2, 204.

25 al-Ṭabarī, Ta'rīkh 1:1002, ll. 3-15.

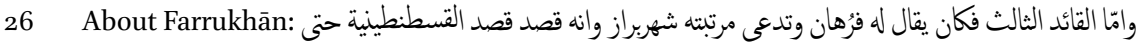

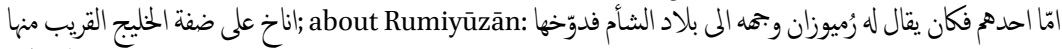

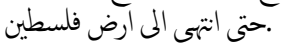

27 al-Ṭabarī, Ta’rīkh 1:1002, فاذوضبان المغرب, cf. Sebeos, The Armenian history 111 (p. 64), "Then came Shahēn Patgosapan ...," also at 124 (p. 81). Note al-Balādhurī's description of the governor (marzbān) of Ișfahān at the time of the conquest (al-Balādhurī [d. ca. 892], Futūh al-buldān 309, وكان مرزبانها مسنا يسمى الفادوسفان. Al-Balādhurī, Origins 486).

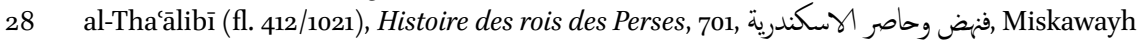
(d. 421/1030), Tajārib al-umam, 1:230. The earliest source is al-Zuhri (d. c. 741) cited Ibn 'Abd al-Hakam, cf. Kaegi and Cobb 2008, 106, 108. So too in the anonymous author of the Nihãyat al-arab fì akhbār al-Furs wa'-'Arab, cf. Dāneš-Pažūh 1996, 424, lines 17-18 ('Shahriyār'), and Eutychius, Ann., 28, ed. Breydy 1985, 121, lines 1-2 (Arabic).

29 Sebeos, The Armenian history 129 (p. 88).

30 Chronicle composed AD 640, AG 934, in Palmer, The seventh century 18, with n. 115,
} 
attribute these operations to Shahrvaraz, and Alexandria would have been a perfect base from which to conduct them. From the summer of 624 to the start of the 626 campaigning season when Persian troops massed for the invasion of Anatolia, Shahrvaraz was back in Persia, pursuing Heraclius who had opened a major counter-offensive in April of $624 \cdot{ }^{31}$ In August 626, following the abortive siege of Constantinople, Shahrvaraz withdrew, probably to Alexandria. ${ }^{32}$ By this stage there was huge disaffection in the ranks of the Sasanian army and Shahrvaraz's return to Egypt and refusal to come to Khusrō's aid the following year when Heraclius launched his second counter-offensive in September 627 , were symptomatic of the crisis that culminated in the removal and execution of Khusrō in February 628. ${ }^{33}$ In other words, as the Persian counteroffensive of 626 faltered, tension seems to have developed between Shahrvaraz and Khusrō, ${ }^{34}$ and it is even possible that there was a mutiny in the armies stationed in Asia Minor. At any rate, a rumour circulated that Shahrvaraz had come to a deal with Heraclius. ${ }^{35}$

Kavād II, Khusrō's son, who consented to his execution, sued for peace within days of his accession. ${ }^{36}$ In April, in the presence of the Roman ambassador Eustathius, Kavad dictated a letter to Shahrvaraz, instructing him that "he should collect his troops, come back into Persia, and abandon Greek territory." ${ }^{37}$ Thus Shahrvaraz was still in former Byzantine territory in April 628

'Dionysius' 30, in Palmer, The seventh century 133, Mich. Syr., Chronique 2:408, Bar Hebraeus, The chronography 1:89.

31 See Howard-Johnston, Heraclius' Persian campaigns, esp. 16-26, for a lucid discussion of the chronology of these campaigns.

32 Cf. Mango, Deux études sur Byzance 109.

33 Disaffection: 'Dionysius' $34^{-35}, 37$, in Palmer, The seventh century $136 \mathrm{f}$., referring to the "general mutiny led by Shahrvarāz," al-Ṭabarī, Tảīikh 1:1005, فاخربحم بهذا الكتاب الى الخلاف . Refusal to aid Khusrō: Sebeos, The Armenian history 127 (pp. 84-85), "Heraclius arrived and camped nearby, outside the city of Ctesiphon; he burned all the royal palaces around the city ... However, Khoream did not come to the aid of king Khosrov, but remained right where he was in the west."

34 For a sample of the legends that evolved around their tense relationship, see ps.Jāhịiz, Kitāb al-tāj 182 ff., ps.-Jāḥiẓ, Livre $198 \mathrm{ff}$.

35 The Syriac sources, Theophanes, etc. make much of a tradition that Shahrvaraz changed sides or made a secret deal with the Byzantines: 'Dionysius' 35 (p. 137), 38 (p. 138), Theophanes, (Chronicle 452-453) AM 6118, al-Mas'ūdì (d. 345/956), Les Prairies d'or 1:242, Mich. Syr., Chronique 2:408-409, Bar Hebraeus, The chronography 1:89, Histoire Nestorienne ii, 87 (p. 41).

36 Negotiations started on 3 April, about five weeks after Kavād's accession, Chronicon Paschale, 187, under the year 628; Sebeos, The Armenian history 127-128 (p. 85), Thomas Artsruni, History 162.

Sebeos, The Armenian history 128 (p. 86). 
and reluctant to leave. In fact, no formal evacuation of the occupied territories occurred till June 629, the date given for the evacuation of Egypt and Syria by the chronicle of $640 .{ }^{38}$ This confirms Sebeos' testimony that Shahrvaraz evacuated Alexandria on the eve of his famous treaty with Heraclius which is dated July 629. The largely Armenian and Greek tradition that Shahrvaraz finally agreed to the withdrawal of troops because Heraclius offered to back a bid for power against the ruling dynasty, now represented by the child Ardashir (Kavād's son), seems credible to me, but it does encounter the obvious difficulty of why Shahrvaraz waited a whole nine months before the putsch of April 630 in which he murdered Ardashir and usurped power. ${ }^{39} \mathrm{He}$ himself was hated by the aristocracy and managed to survive for only forty days. ${ }^{40}$

To return to 'Shahralanyozan,' Dieter Weber's suggestion that we should take this as a name meaning "die Alanen bekämpfend" opens a new line of enquiry. ${ }^{41}$ Shahralanyozan-Farrukhan himself was clearly fond of nicknames that drew attention to his reputation as an intrepid warrior. Both 'Shahrvaraz' (literally 'Wild boar of the realm' with the actual meaning 'Hero of the realm') ${ }^{42}$ and 'Razmyozan' ('Stirring up the regiments'? 'Throwing the battle lines into confusion'? $)^{43}$ did precisely this, and so presumably did 'Shahralanyozan.' A form of this name is attested in the Armenian aristocracy of the fourth century,

38 Chronicle, AG 930, in Palmer, The seventh century 17-18.

39 It is possible that he was busy fighting the Khazars and even used the Khazar threat as the pretext for toppling Ardashir, as Movsēs Dasxurants'i claims, The history 104-105 (cf. Flusin, Saint Anastase 2:306 ff.). S. was clearly installed in power with Heraclius' backing, cf. Sebeos, The Armenian history 129 (p. 88; Heraclius bestows the throne on S. and his offspring), and the discussion in Mango, Deux études sur Byzance $110 \mathrm{ff}$. , which concludes, "c'est Héraclius qui décida d'installer Šahrvaraz sur le trône persan ... il lui promit la couronne et, après lui, à son fils." The strongest formulation of this is in Vardan Arewelc' $i$ (Thomson, The historical compilation 174), "When Heraclius heard this [news of Kavād's demise], he urged Xorem to seize the crown by murdering the youth [Ardashir]"(!!).

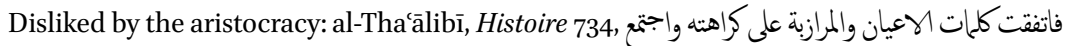
المتفرقون على بغضه ,cf. al-Dīnawarī, Kitāa al-akhbār 116, al-Ṭabarī, Tảrīkh 1:1063, both attributing s.'s assassination to the nobility_كثير من العظماء واهل البيوتات (al-Ṭabarī). Shahrvaraz's

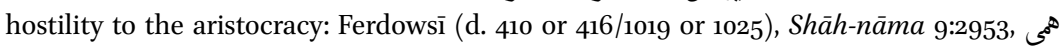
دارد او مهتران را سبك, cf. Sebeos, The Armenian history 130 (p. 88), "All the principal men at court or in the army in whom he could place no trust he commanded to be put to the

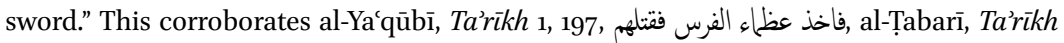
1:1062, l. فاخذ جاعة من الرؤساء فقتلهم 14.

41 Weber, Ein bisher unbekannter.

42 Cf. Monchi-Zadeh, Die Geschichte 63, 'Phl. varāz, np. Gurāz "Eber" $\rightarrow$ "Held"'

43 Justi, Iranisches Namenbuch 26o, s.v. Razmiozan, renders the meaning as 'Kampf aufsuchend', and most scholars have repeated this, e.g. Nyberg, A manual of Pahlavi 2:40: 
where it clearly implies a reference to the Alans to their north. ${ }^{44}$ In the sixth century much of the central and eastern Caucasus was dominated by the Alans, Procopius says so in so many words, ${ }^{45}$ and Alan raids across the Caucasus would undoubtedly have been a major reason for Khusrō Anoširavan's massive projects of construction and fortification in the sub-Caucasian region. ${ }^{46}$ The Sasanian objective of holding the passes through the Caucasus against barbarian pressure from the north fructified in a vast defensive system which is in fact best described in Arabic sources such as al-Balādhurī and Ḥamza al-Iṣfahānī, and a valuable passage in Ibn Khurradādhbih. Darial in the Central Caucasus and Darband on the western shore of the Caspian were pivotal to this system. ${ }^{47}$ The former, of course, derives its name from 'Dar-i Alān', Ar. Bāb al-Lān. Alan settlements were widely dispersed in the seventh century. ${ }^{48}$ The Arme-

MPrth $r z m y(y) w z$ 'eager for battle'; to me it seems likely that the name contains a stronger Avestan allusion, esp. to Avesta, Yasht 14, 62 (n. 59 below), where the object of yaoz- is rasmanō (rasman-, 'regiment,' 'Schlachtreihe, Phalanx'; for $y(a)$ ozan cf. n. 59). Note the pronunciation implied in the earliest (almost contemporary) transcriptions of the name, viz. 'P $\alpha \sigma \mu \iota \zeta \alpha v$ in the Lives of John the Almoner and Rasmiozan/Rasmiozdan in Strategius (n. 18 above).

44 Cf. Garsoïan, The epic histories 344-345.

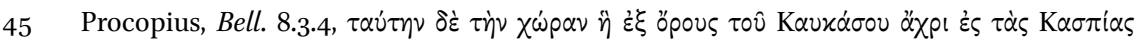

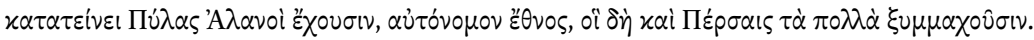

46 One can get some sense of the scale of these investments from reports (especially in Yāqūt and al-Ya'qūbī) about the quality of Khusrō's constructions at Darband, Yāqūt (d. 626/1229), Mujam al-buldān 1:440, al-Ya'qūbī cited Ibn al-Faqīh (fl. 289/902), Kitāb al-buldān 290 ff., cf. Ya'kūbī, Les Pays 232-233, with Barthold, Derbend esp. 941, Kettenhofen, Darband esp. 15-16, al-Ṭabarī, Ta’rīkh 1:895, says he built "towns, castles, ramparts and numerous structures" throughout the region, with stone transported from Gurgān, فينيت فى ناحية صول بصخر منحوت فى ناحية جرجان مدن وحصون وآكام وبنيان كثير Al-Thac̄libī, Histoire

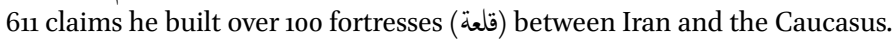

47 Darial is listed among the provinces ( $h s h t r)$ of the empire in Shapur I's victory inscription at Naqsh-e Rustam, where it is called 'the Alan gate' (Parth. 'l ' $n n B B^{\prime}$ ), see Back, Die sassanidischen $286-287$ (text), 187-188 (commentary). It was a Sasanian stronghold in 466, cf. Priscus fr. 37 in Müller, Fragmenta iv, 107, and Marquart, Ërānšahr nach der Geographie $99 \mathrm{ff}$., but subsequently lost to the Huns. Movses Dasxurants'i, The history 66 refers to a marzbān of Ç̣ołay in the mid-5th century, suggesting that much of the coastal region was under Sasanian control by then, before the emergence of Darband as a substantial fortified site.

48 From their strongholds in the Central Caucasus (Darial, etc.) to the western shores of the Caspian, north of Darband. According to al-Balādhurī, Khusrō I met the Turks at al-Barshaliyya, Futūh al-buldān 199 (برشلية), not far north of Darband. This was Barsāliā (= Bashli?), the name by which the Alan country was known in this region, cf. Mich. Syr., 
nian Geography of Ananias of Širak tells us that the Massagetae (Alans) dwelt "as far as the Caspian Sea to which a branch of the Caucasus extends. Here is the wall of Darband, the town of the Chor pass (k'atak'pahakin Čora), with its great rampart built in the sea." ${ }^{49}$ Armenian pahak Čra has an exact equivalent in the Arabic Bāb Ṣūl, and al-Ṭabarì's expression nāhiyat Șūl wa-Alān can be read as implying that Alan territory impinged on Darband..$^{50}$ Both Kavād I and Khusrō I invested massively in the fortification of Daghestan, constructing fortresses throughout the region and assigning these and their garrisons to local rulers. ${ }^{51}$ Khusrō was responsible for the creation of a formal system of rulership, with titles such as Sharvān-shāh, Ṭabarsarān-shāh, Alān-shāh, and so on. ${ }^{52}$ According to Hamza, these Transcaucasian rulers were assigned hereditary estates. ${ }^{53}$ Darband itself would undoubtedly have had a Sasanian in control. The History

Chronique 2, 364 and Marquart, Ërānšahr nach der Geographie 485ff., concluding, "Damit ergibt sich die Lage des Landes Barsāliā von selbst: es muss sich im Süden bis Darband, im Norden mindestens bis zu den Ebenen am Sulak und Terek erstreckt haben." Repeated Alan (Ossete, Mazk' $\mathrm{ut}^{c} \mathrm{k}^{c}$ ) raids through Darband and the passes south of Darband (e.g. Moses Khorenatsi, The history 9, Thomson, The historical compilation 161, etc.) is also proof of a widespread Alan presence in this sector.

49 The geography 57; cf. Moses Dasxurançi, The history 155, "the gate of C̣̆ołay which is near Darband."

$50 \quad$ al-Ṭabarī, Ta’rīkh 1:895, ناحية صول al, al-Ṭabarī, The history, 152.

$5^{1} \quad$ al-Balādhurī, Futūḥ al-buldān 198; Ibn Khurradādhbih (d. ca. 300/911), Kitāb al-Masālik 123; Ibn al-Faqīh, Kitāb al-Buldān 344; al-Ṭabarī, Ta’rīkh 1:895, l. 7 ff. Kavād's foundations describe an arc through eastern Albania/Arrān into southern Daghestan, up to the "long wall called Apzutkawat" (Abzüd kavād, 'Kavād extended this') that connected the mountains to the Caspian north of Shapotran, Ananias of Širak, The geography 57 (long rec.); Hudūd al-'̄lam 401. Kavād also seized Darial from the Huns and placed a permanent garrison there, against the Massagetai (= Alans, cf. Dio Cassius, lxix, 15, Amm.Marc. 23.5.16, 31.2.12), Procop., Bell., 1.10.12 (seizure), 1.16.4ff. (garrison). Darband was chiefly fortified by Khusrō I, with the famous wall that protruded into the sea and the imposing network of forts in the mountains to the west, al-Iștakhrī (wr. ca. 951), al-Masālik 184ff., n. $i$; al-Balādhurī, Futūḥ al-buldān 199. In the Sīrat Ānūshirwān Khusrō claimed he settled thousands of Turkish auxiliaries in these regions, subordinating them to the marzbān of Șūl, cf. Grignaschi, Quelques spécimens 19ff., 24. "Pērōzkhusrō", ibid., 19, was surely Khusrō's name for Darband, cf. Miskawayh, Tajärib al-umam (n. 28) 192, l. 8 ff., فلما بلغت باب الصل ومدين فيروز خشرو.

$5^{2}$ al-Balādhurī, Futūḥ al-buldān 199-200, Ḥamza al-Ișfahānī (ca. 350/961), Tảrīkh sini mulūk 58, al-Mas'ūdī, Les Prairies d'or 1, 16o, and the ref. in the Sirrat Ānūshirwān to al-mulükmin qibalanā hunāka (Miskawayh, Tajārib al-umam 192, Grignaschi, Quelques spécimens 19).

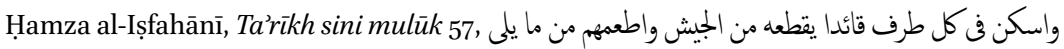
الكلك الصق ضياعا وجعلها من بعدهم وقفا على اولادهم. 
of Tabaristān mentions a nephew of Khusrō, Narsī, as the "lord of Darband" (șāhib hurūb Darband). ${ }^{54}$ Before his own accession to power, Khusrō Parvez bore the title 'Alānshāh, underlining the centrality of Darband to the Sasanian defence system in the late sixth century. ${ }^{55}$ The eleventh-century Ta'rikh Bāb al-abwāb preserved in Münejjim-bashïs Jāmia' al-duwal makes repeated use of the expression 'al-Bāb and the Marches' (Bāb al-abwāb wa-l-thughūr). ${ }^{56}$ This recalls the late Sasanian terminology preserved in a valuable passage of the famous Letter of Tansar, a third-century original that was re-edited in the sixth century, where the founder of the dynasty Ardashir is supposed to tell his priests, "if any man come submissively before us, seeking to walk upright upon the highway of obedience, we shall not deprive him of the title of king. No other man, not being of our house, shall be called king, except the Lords of the Marches — of the Alān and the western region, of Xwārezm and Kābul."57 Thus 'Alānshāh' was one of the titles of the commander assigned to Darband and the Marches, and it was this position, I suggest, that Hormazd conferred on Khusrō Parvez, presumably to give him control of a substantial body of troops. ${ }^{58}$ More speculatively, I suggest that on his accession to the throne, Khusrō transferred this command to Farrukhān, who was not yet Shahrvaraz, perhaps modifying the title to remove any reference to 'king'. If 'Shahralanyozan' was another of his fancy names for this general, it may have been an allusion to the Avestan image of the goddess Anāhìt "stirring up the shores of the sea Vourukaša" (in the Aban yašt or 'Hymn to the waters'), or of VərəӨrayna, the god of Victory, throwing the battle lines into confusion. ${ }^{59}$ Among her various attributes, Anāhitā was

54 Ibn Isfandiyār (wr. 613/1216-1217), Tarikh-i Tabaristan 153, Ibn Isfandiyār, An abridged translation 97.

55 Ferdowsī, Shāh-nāma 9, 2694, الان شاه مارا يُر كرده بود / كه بر ماز دام تو ازرده بود cf. Alemany, Sixth-century Alania, who notes the parallel with Pahl. sht'l'nywc'n. There is an interesting resonance of this in Juansher's Life of Vaxt'ang Gorgasali, Thomson, Rewriting Caucasian history 228, "Then the king of the Persians Urmizd gave Ran and Movakan to his son, who was called K'asre Ambarvez. He came and resided at Bardav ...'

56 Minorsky, A history of Sharvān, 41, 47; e.g. Ar. 16: باب لابواب والثغور.

57 Ibn Isfandiyār, Tansar's Epistle to Goshnasp 9, l. 16f. جز ان جاعت كه اصحاب ثغورند الان و ناحيت لابوابور مغغرب و خوارزم وكابل, Ibn Isfandiyār, The Letter of Tansar 35.

$5^{8}$ This is implied in the reason Khusrō gives for his appointment, cf. Ferdowskī in n. 55 above.

59 Avesta, Yasht 5, 4: yaōzenti vīspe karanō zraiiā vōuru-kashaiiā, also in 8, 31 (Panaino, Tištrya, I 55); 10,36: yaōzenti vīspe karanō rasmanō arezō-shütahe (Gershevitch, The Avestan hymn 90, "all the flanks are surging of the battled-tossed regiments"), in all of which the verb form is intransitive. (For the transcription of intervocalic $i i$, see Hoffmann and Narten, Der Sassanidische Archetypus $39 \mathrm{ff}$.) The stronger, transitive use occurs in Avesta, Yasht 8, 
also the goddess of war. ${ }^{60}$ The yašts which have a more distinctly epic character were favourite songs sung by warriors, and the verb yaoz- which appears repeatedly in the yashts should be taken in its late Avestan sense of 'confounding,' 'throwing into turmoil' or 'stirring up.'61 Thus I would suggest 'throwing the land of the Alans into turmoil' as a likely translation of 'Shahralanyozan.'

Whatever one thinks of this reconstruction, it is interesting that according to a tradition transmitted by Sayf ibn 'Umar and reported in al-Ṭabarī, a descendant of Shahrvaraz was 'ruler of Darband' (malik bi al-Bāb) at the time of the first Arab incursion into Transcaucasia in $643 .{ }^{62}$ What should we make of this? In Termination of Hostilities Donald Hill commented, "It is extremely unlikely that any Muslim forces penetrated into the country of the Khazars at such an early date." ${ }^{33}$ This seems to imply that Darband was now under Khazar control. To me it seems more likely that the Sasanian contingents called the Siyasikin or Nishastagan retained control of Darband into the early 640s, when the rest of the empire had fallen apart. The backbone of this isna $\bar{a}$, one repeatedly used by Sayf, may have been a compilation of reports reduced to writing by Talhah ibn al-A'lam. In any case, the long-standing prejudice against Sayf's reliability as a transmitter has now begun to disintegrate. I only mention this report in conclusion because it fits into the general framework of my argument so well.

8 (Panaino, Tištrya, I 34): āpō yaozaiieiti (in tmesis with upā and aißi), and most spectacularly in 14,62 (the hymn to Victory), where the god VərəӨraץna does various things to the battle lines (rasmanō), including "throwing them into confusion"-yō rasmanō yaōzaiieiti. Translations of the passage from Yasht 14 include Malandra, An introduction 87, "We worship Ahura-created Wərəthraghna, who destroys the battle lines, who cuts the battle lines, who tramples the battle lines, who throws the battle lines into confusion..," and Avesta 267, "der die Schlachtreihen zerstört, der die Schlachtreihen zerschneidet, der die Schlachtreihen ins Gedränge bringt, der die Schlachtreihen in Verwirrung bringt."

6o E.g. Chaumont, Le culte d'Anāhitā. The figure of Anahita presided over Khusrō's expansion into the eastern provinces, see Malek, The Sasanian king, discussing Khusrō's special issues that begin $c$. 610, with reverse types that replace the fire altar with a facing bust of the goddess. Malek notes that "The cult of Anāhitā was in its ascendancy under Khusrau II" (p. 35).

61 See Bartholomae, Altiranisches Wörterbuch 1231, s.v. yaoz-, 2a caus. 'in Verwirrung bringen', Boyce, $A$ word-list 103, ywz- [yōz-] Pth. 'agitate, set in motion, convulse; be agitated'.

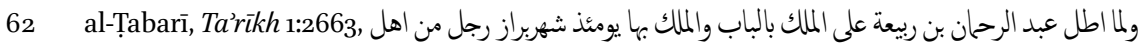

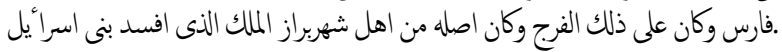

63 Hill, Termination of hostilities 155 . 


\section{Bibliography}

\section{Primary Sources}

Ananias of Širak (7th century), The geography of Ananias of Širak (Ašxarhac'ouc ). The long and the short recensions, ed. R.H. Hewsen, Wiesbaden 1992.

Anastasios of Persia (d. 628), Saint Anastase le Perse et l'histoire de la Palestine au début du viI ${ }^{e}$ siècle, 2 vols., ed. B. Flusin, Paris 1992.

Avesta, ed. F. Wolff, Berlin 1924.

al-Balādhurī (d. 297/892), Futūḥ al-buldān, ed. R.M. Radwan, Cairo 1932. The origins of the Islamic state, ed. and trans. P.K. Hitti, New York 1916.

Bar Hebraeus (1226-1286), The chronography of Gregory Abü'l Faraj ... known as Bar Hebraeus, ed. E.A. Budge, London 1932.

Chronicon Paschale 284-628A.D., eds. M. Whitby and M. Whitby, Liverpool 1989.

al-Dīnawarī (d. 282/896), Kitāb al-akhbār aț-țiwāl, ed. V. Guirgass, Leiden 1888.

Ferdowsī (d. 411/1020), Šāh-nāma, 10 vols., ed. S. Nafīsī, Teheran 1933-1936.

Eutychius of Alexandria (d. 329/940), Das Annalenwerk des Eutychios von Alexandrien (csco, Scr. Arabici t. 44). ed. M. Breydy, Louvain 1985.

Ḥamza al-Iṣfahānī (d. 349/961), Ta’rīkh sinimulūkal-arḍ wa-l-anbiyā, ed. I.M. Gottwaldt,

St. Petersburg 1844.

Hudūd al-'̄̄lam, ed. V. Minorsky, London 1937.

Ibn al-Athīr (d. 630/1233), al-Kämil fi al-ta'rīkh, 12 vols., ed. C.J. Tornberg, Leiden 1867, repr. Beirut 1965 .

Ibn al-Faqīh al-Hamadhānī (d. 330/941), Kitāb al-buldān (Bibliotheca Geographorum Arabicorum 5), ed. M.G. de Goeje, Leiden 1885, repr. 1967.

—. Abrégé du Livre des Pays, ed. and trans. H. Massé, Damascus 1973.

Ibn Isfandiyār, Tarikh-i Tabaristan, Tehran 1941.

. An abridged translation of the history of Tabaristán compiled about A.H.613

(A.D.1216) by Muhammad ibnal-Hasan ibn Isfandiyár, trans. E.G. Browne, Leiden and London 1905 .

Ibn Isfandiyār (fl. c. 613/1216), The letter of Tansar, trans. M. Boyce, Rome 1968.

—. Tansar's epistle to Goshnasp ... Persian text, ed. M. Minovi, Teheran 1932.

Ibn Khurradādhbih (d. 300/912), Kitāb al-masālikwa-l-mamālik (Bibliotheca Geographorum Arabicorum 6), ed. M.G. de Goeje, Leiden 1889.

al-Ișțakhrī (d. 346/957), al-Masālikwa-l-mamālik (Bibliotheca Geographorum Arabicorum 1), ed. M.G. de Goeje, Leiden 1870.

ps.-Jāḥiz, Kitāb al-Tāj, ed. A. Zéki Pasha, Cairo 1914.

- Le livre de la couronne, ed. and trans. Ch. Pellat, Paris 1954.

Khuzistan Chronicle = Chronica Minora I. (csco, Scr. Syri t.1), ed. I. Guidi, Louvain 1955 .

Leontius of Neapolis (7th century), Vie de Syméon le Fou et Vie de Jean de Chypre, dit

l'Aumônier, ed. A.-J. Festugière, Paris 1974. 
al-Mas'ūdī (d. 346/957), Murūj al-dhahab wa-ma'ādin al-jawhar / Les Prairies d'or, ed.

C. Barbier de Meynard and A. Pavet de Courteille, Paris 1861-1877.

Michael the Syrian (d. 1199), Chronique de Michel le Syrien patriarche Jacobite d'Antioche (1166-1199), ed. and trans. J.-B. Chabot, Paris 1901, repr. 1963.

[Ibn] Miskawayh (d. 420/1030), Tajārib al-umam, vol. 1, facs (Gibb Memorial vol. vii, 1), ed. L. Caetani, Leiden and London 1909.

Movses Dasxurants'i (d. ca. fl. 1oth century), The history of the Caucasian Albanians by Movsēs Dasxurançi, trans. C.J.F. Dowsett, London 1961.

Müller, C., Fragmenta Historicorum Graecorum, 5 vols, Paris 1878-1885.

Nihāyat al-'arab fì akhbār al-furs wa-l-'arab, ed. M.T. Dāneš-Pažūh, Tehran 1997.

Nikephoros (d. 815), Nikephoros: Short history (Corpus Fontium Historiae Byzantinae xiii), ed. C. Mango, Washington, DC 1990.

Procopius (d. ca. 565), De Bellis. Ed. and tr. H.B. Dewing. Cambridge Ms, 1914.

Sebeos (7th century), The Armenian history attributed to Sebeos, 2 vols., ed. R.W. Thomson, Liverpool 1999.

Stephanos Asoghig (1oth/11th century), Histoire Universelle par Etienne Açogh'ig de Daron. Première partie, trans. E. Dulaurier, Paris 1883.

al-Ṭabarī (d. 310/922), Ta'rīkh al-rusul wa-l-mulūk, Leiden 1879 .

. The history of al-Tabarī, vol. v: The Sāsānids, the Byzantines, the Lakhmids, and

Yemen, trans. C.E. Bosworth, Albany, NY 1999.

al-Thaālibī (d. 427/1036), Histoire des rois des Perses, ed. H. Zotenberg, Paris 1900.

Thomas Artsruni (c. 9oo), History of the House of Artsrunikc, trans. R.W. Thomson, Detroit 1985.

Theophanes (d. 817 or 818), The chronicle of Theophanes Confessor: Byzantine and Near

Eastern history A.D. 284-813, eds. C. Mango and R. Scott, Oxford 1997.

Theophylact Simocatta (late 6th century), The history of Theophylact Simocatta, eds.

M. Whitby and M. Whitby, Oxford 1986.

Yāqūt (d. 310/1229), Kitāb mu'jam al-buldān, ed. F. Wüstenfeld, Jacut's geographisches

Wörterbuch, 6 vols, Leipzig 1866-1873.

al-Ya‘qūbī (d. 284/897), Ta’rīkh, 2 vols., ed. M.T. Houtsma, Leiden 1993.

. [Ya kāūbī], Les Pays, trans. G. Wiet, Cairo 1937.

\section{Secondary Sources}

Alemany, A., Sixth-century Alania, in Webfestschrift Marshak 2003, accessed 10 Apr 2014, www.transoxiana.org/Eran/Articles/alemany.pdf.

Back, M., Die sassanidischen Staatsinschriften (Acta Iranica 18), Leiden and Tehran 1978.

Barthold, W., Derbend, in $E I^{1}$ I, 940-945.

Bartholomae, C., Altiranisches Wörterbuch, Strassburg 1904.

Boyce, M., A word-list of Manichaean Middle Persian and Parthian (Acta Iranica 9a), Teheran and Liège 1977 . 
Cereti, G., On the Pahlavi Cursive Script and the Sasanian Avesta, in Studia Iranica 37 (2008), 174-195.

Chaumont, M., Le culte d'Anāhitā à Staxr et les premiers Sassanides, in Revue de l'Histoire des Religions 153 (1958), 154-175.

Delehaye, H., Vie anonyme de Jean l' Aumônier (B H g 8872), in Assyrologische Bibliothek 45 (1927), 5-74.

Flusin, B., Saint Anastase le perse et l'histoire de la Palestine au début du viIe siècle, 2 vols, Paris 1992.

Garitte, G., La prise de Jérusalem par les Perses en 614 (csco vol. 203, scr. Iberici t. 12), Louvain 1960.

- Expugnationes Hierosolymae A.D. 614: Recensiones arabicae (Csco vol. 347, scr. Arabici t.26), Louvain 1974.

Garsoïan, N.G. (trans), The epic histories attributed to P'awstos Buzand, Cambridge, Mass. 1989.

Gershevitch, I., The Avestan hymn to Mithra, Cambridge 1959.

Greenwood, T., Armenian neighbours (600-1045), in J. Shepard (ed.), The Cambridge history of the Byzantine empire c. 500-1492, Cambridge 2008.

Grignaschi, M., Quelques spécimens de la littérature Sassanide conservés dans les bibliothèques d' Istanbul, in Journal Asiatique 254 (1966), 1-142.

Gyselen, R., The four generals of the Sasanian Empire: Some sigillographic evidence, Rome 2001.

- Sasanian seals and sealings in the A. Saeedi Collection (Acta Iranica 44), Louvain 2007 .

- Primary sources and historiography on the Sasanian Empire, in Studia Iranica 38 (2009), 163-19o.

Hill, D.R., Termination of hostilities in the early Arab conquests, London 1971.

Hoffmann, K. and J. Narten, Der Sasanidische Archetypus. Untersuchungen zu Schreibung und Lautgestalt des Avestischen, Wiesbaden 1989.

Howard-Johnston, J., Heraclius' Persian campaigns and the revival of the East Roman Empire, 622-630, in War in History 6 (1999), 1-44.

Armenian historians of Heraclius, in G.J. Reinink and B.H. Stolte (eds.), The reign of Heraclius (610-641): Crisis and confrontation, Leuven 2002, 41-62.

Hübschmann, H., Armenische grammatik, I/I, Leipzig 1895.

Justi, F., Iranisches namenbuch, Marburg 1895.

Kaegi, W. and P.M. Cobb, Heraclius, Shahrbarāz, and al-Ṭabarī, in H. Kennedy (ed.), Al-Tabari: A medieval Muslim historian and his work, Princeton, NJ 2008.

Kellens, J. and E. Pirart, Les textes vieil-avestiques, 2 vols., Wiesbaden 1990.

Kettenhofen, E., Darband, in E. Yarshater (ed.), Encyclopaedia Iranica, VII, New York 1994, 13-19.

Lappa-Zizicas, E., Un épitomé inédit de la vie de S.Jean l' Aumônier par Jean et Sophronios, in Assyrologische Bibliothek 88 (1970), 265-278. 
Malek, M., The Sasanian king Khusrau II (A.D. 590/1-628) and Anāhitā, in Nāme-ye Irān-e Bastan 2 (2002), 23-43.

Malandra, W.M., An introduction to ancient Iranian religion, Minneapolis 1983.

Mango, M., Deux études sur Byzance et la Perse sassanide, in Travaux et Mémoires 9 (1985), 91-118.

Marquart, J., Ërānšahr nach der Geographie des ps. Moses Xorenac I, Berlin 1901.

- Osteuropäische und ostasiatische Streifzüge, Leipzig 1903.

Minorsky, V., A history of Sharvān and Darband in the 1oth-11th centuries, Cambridge 1958.

Monchi-Zadeh, D., Die Geschichte Zarēr's, Uppsala 1981.

Nöldeke, Th., Die von Guidi herausgegebene syrische Chronik. Uebersetzt und commentiert, in Sitzungsberichte der kaiserlichen Akademie der Wissenschaften, phil.hist. Cl. 128 (1893), 1-48.

Nyberg, H.S., A manual of Pahlavi, 2 vols., Wiesbaden 1974.

Olajos, Th., Les sources de Théophylacte Simocatta historien, Leiden 1988.

Palmer, A., The seventh century in the West-Syrian chronicles, Liverpool 1993.

Panaino, A., Tištrya, I: The Avestan hymn to Sirius, Rome 1990.

Pourshariati, P., Recently discovered seals of Wistaxm, Uncle of Husraw II?, in Studia Iranica 35 (2006), 163-180.

Scher, A. and R. Griveau (eds.), Histoire Nestorienne inédite (Chronique de Séert), pt. 2 (Patrologia Orientalis, t. xiii, fasc. 4), Turnhout 1919.

Thomson, R.W., The historical compilation of Vardan Arewelc'i, in Dumbarton Oaks Papers 43 (1989), 125-226.

- Rewriting Caucasian history. The medieval Armenian adaptation of the Georgian chronicles, Oxford 1996.

Tyler-Smith, S., Calendars and coronations: The literary and numismatic evidence for the accession of Khusrau II, in Byzantine and Modern Greek Studies 28 (2004), 33-65.

Weber, D., Pahlavi papyri and ostraca, in W. Skalmowski and A. Van Tongerloo (eds.), Middle Iranian Studies, Leuven 1984, 25-43.

Ein bisher unbekannter Titel aus spätsassanidischer Zeit?, in R.E. Emmerick and D. Weber (eds.), Corolla Iranica: Papers in honour of prof. Dr. David Neil MacKenzie, Frankfurt 1991, 228-235.

- Ostraca, Papyri und Pergamente (Corpus Inscriptionum Iranicarum 3/5), London 1992.

- Eine spätsassanidische Rechtsurkunde aus Ägypten, in Tyche 17 (2002), 185192.

. Berliner Papyri, Pergamente und Leinenfragmente in Mittelpersischer Sprache, London 2003. 